\title{
A comprehensive review of the coffee leaf miner Leucoptera coffeella (Lepidoptera: Lyonetiidae), with special regard to neotropical impacts, pest management and control.
}

Juliana Dantas ${ }^{1}$, Isabela Motta ${ }^{1}$, Leonardo Vidal ${ }^{1}$, Joao Bilio ${ }^{1}$, Júlia M. Pupe', Adriano Veiga ${ }^{2}$, Carlos H.S. Carvalho ${ }^{3}$, Rogerio B. Lopes ${ }^{1}$, Thales L. Rocha ${ }^{1}$, Luciano P. Silva ${ }^{1}$, José R. Pujol-Luz ${ }^{4}$ and Érika V.S. Albuquerque ${ }^{1 *}$

1 Embrapa Genetic Resources \& Biotechnology, Brasília 70770-917, Brazil

2 Embrapa Cerrados, Planaltina 73310-970, Brazil

3 Embrapa Coffee, Brasília 70770-901, Brazil

4 University of Brasilia, Brasília Brazil

* Correspondence: erika.albuquerque@embrapa.br; Tel.: +55-61-3448-4670 (E.V.S.A.)

Simple Summary: Coffee is produced in more than 60 countries by 25 million coffee producers, most of whom are smallholders in emergent countries. More than a beverage intake, coffee drinking has become a ritual for an increasing number of consumers across the globe. This rising market demands modern managing towards enhanced production, environment protection, and highquality pesticide-free products. Amongst several challenges to overcome, the coffee leaf miner (CLM) pest is one of the most severe threatens to the coffee crop, especially in hot and dry climate. Responsible for losses ranging from $3070 \%$, the CLM impairs the grain production and quality, impacting the coffee chain. Drawback aspects of the control by synthetic pesticides, as the harmful effects to human health and environment and the selection of resistant-insect populations, prompt scientists to improve Integrated Pest Management (IPM) tools. Therefore, the development of new resistant cultivars, biological control strategies, nanobiopesticide products and other approaches are important strategies to a sustainable CLM control design. This review addresses basic knowledge of the insect $L$. coffeella and proposes novel insights for an IPM view.

Abstract: The coffee leaf miner (CLM) Leucoptera coffeella moth is a major threat to coffee production. Insect damage is related to the feeding behavior of the larvae on the leaf. During the immature life stages, the insect feeds in the mesophyll, triggering necrosis and causing loss of photosynthetic capacity, defoliation, and significant yield loss to coffee crops. Chemical control is mandatory to sustain the coffee production chain, though market requirements move towards conscious consumption, claiming for more sustainable methods. In this overview, we discuss aspects about the CLM concerning biology, history, geographical distribution, economic impacts, and the most relevant control strategies in progress. Insights to develop an integrate approach for a safer and ecofriendly control of the CLM are discussed, including bio-extracts, nanotechnology, pheromones, and tolerant cultivars.

Keywords: resistance; cultivar; biopesticide; biological control; chemical control; life cycle; CLM

1. Introduction 
Since the legend of Kaldi, dating from the VI century, coffee consumption expanded from goats to human beings and has been increasingly gaining followers. Although coffee is a non-essential food commodity, its commercial chain is one of the most profitable and complex in the world. Its stakeholders operate not only in planting, harvesting, roasting, packaging, transporting, and blending, but also in wholesale and retail marketing ranging from modest diners to sophisticated restaurants and high-profile tasting contests. The challenges for maintaining this productive chain are many, among which are the pests that threaten the crop, including the coffee exclusive enemy Leucoptera coffella (Lepidoptera: Lyonetiidae).

L. coffeella, the coffee leaf miner (CLM), is considered one of the most important coffee pests due to the high damage this moth causes to coffee plantations. Estimated losses in neotropical producing countries can reach up to $87 \%$ of the coffee productivity, depending on the season, the defoliation can reach up to $75 \%$ [1,2]. Damage to coffee yield in Colombia exceeds 50\% [3,4]. Productions suffer losses ranging from $20 \%$ to $40 \%$ in Puerto Rico and around $12 \%$ in Mexico $[5,6]$. The CLM incidence surveys are flawed because the monitoring is done by sampling mined leaves or traps. New systems employing aerial images and terrestrial photogrammetry are being developed to facilitate the detection of the incidence of this pest in the field $[7,8]$.

Preventive chemical control has been circumvented in the insect populations by resistant individuals to most of the insecticides currently in use. Although important as natural mortality factors, biological control agents present limitations in their efficiency when used as a stand-alone strategy. Biotechnological strategies can generate products to meet the demand for sustainable, durable, and safe solutions for specific control of the CLM.

\section{History, Origin, and Distribution}

Despite its origin on the African continent [9,10], CLM was first reported 178 years ago in coffee plantations in the Caribbean Antilles [11]. It was first named Elachista coffeella, then assigned to Bucculatrix sp (Stainton, 1858) and later in Cemiostoma sp. (Stainton, 1861). Finally, it was included in the genus Leucoptera (Meyrick, 1895) and named L. coffeella in 1897 by Lord Walsingham. It was already reported as Perileucoptera coffeella, a synonymous [12].

L. coffeella is now a cosmopolitan pest (Figure 1a) and occurs in the leaves of coffee plants in Africa, Asia and Neotropical countries, comprising Central America, the Caribbean islands and South America [9,13-15]. In Brazil, the presence of CLM was detected around the 19th century and became a key pest of coffee culture in the country [16]. Since then, wherever coffee is grown, the CLM is present [17-19] (Figure 1b). 


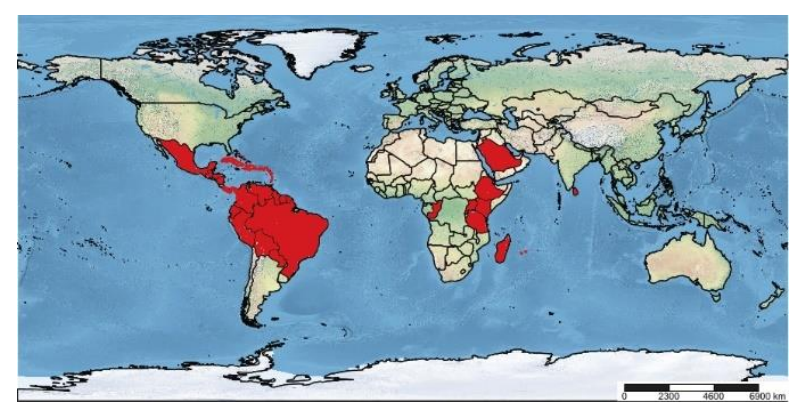

(a)

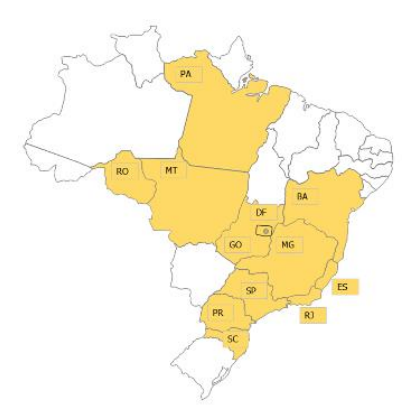

(b)

Figure 1. Presence of L. coffeella in: (a) The world map, showing producing countries highlighted in red: North and Central America: Antigua and Barbuda, Barbados, Costa Rica, Cuba, Dominica, Dominican Republic, El Salvador, Grenada, Guadeloupe, Guatemala, Haiti, Honduras, Jamaica, Martinique, Mexico, Montserrat, Nicaragua, Puerto Rico, Saint Lucia, Saint Vincent and Grenadines, Trinidad and Tobago; South America: Bolivia, Brazil, Colombia, Ecuador, French Guiana, Guyana, Peru, Suriname and Venezuela; Africa: Reunion, Mauritius, Madagascar, Uganda, Kenya, Congo, Ethiopia, Tanzania and Rwanda; Asia: Saudi Arabia and Sri Lanka, and (b) Brazil, highlighting in yellow the affected producing states : $\mathrm{RO}=$ Rondônia, $\mathrm{MT}=$ Mato Grosso, $\mathrm{PA}=$ Pará, GO = Goiás, DF $=$ Distrito Federal, $\mathrm{BA}=$ Bahia, $\mathrm{MG}=$ Minas Gerais, $\mathrm{ES}=$ Espírito Santo, $\mathrm{SP}=$ São Paulo, RJ = Rio de Janeiro, $\mathrm{PR}=$ Paraná, $\mathrm{SC}=$ Santa Catarina.

\section{Biology}

\subsection{Life cycle}

L. leucoptera is an holometabolous insect [20], (Figure 2). Considering a $25^{\circ} \mathrm{C}$ temperature, the egg stage usually lasts about five days, twelve days for the larval development and more five days as pupae, totaling about 22 days until reaching adulthood [21]. Total life cycle varies according to temperature, relative humidity, and rainfall. In the dry season, the attack of the pest is usually stronger than in wet periods $[22,23]$. 
(a)

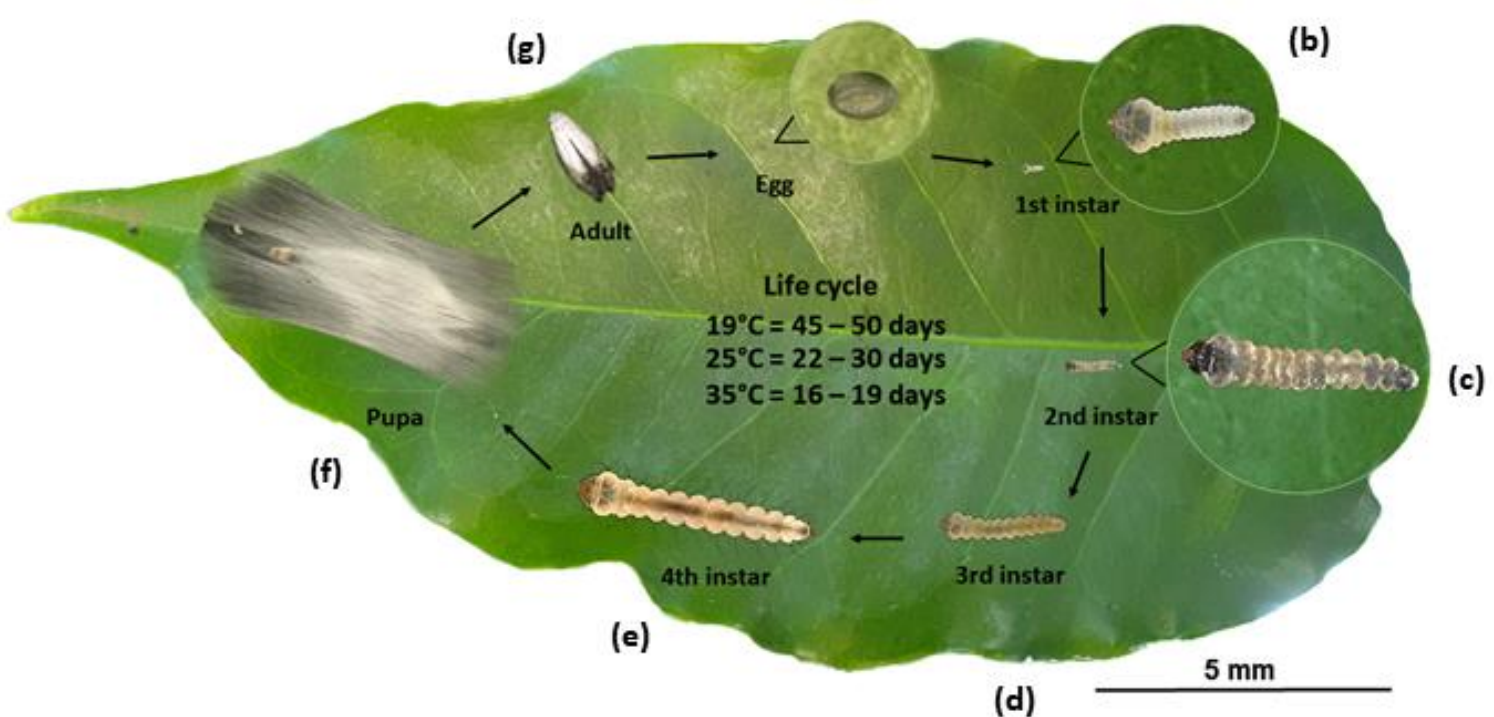

Figure 2. L. coffeella life stages from egg to adult. After hatching the egg, (a) the larvae development is divided in 4 instars: L1 (b), L2 (c), L3 (d) and L4 (e). The last instar forms a cocoon and turn into pupa (f). The adult emerges (g) from the pupa to mate. Eggs are laid over the adaxial side of the coffee leaf and the cycle restarts. Temperature rising accelerates and shortens the cycle span time, as detailed.

The egg is about $0.3 \mathrm{~mm}$, made by a translucent structure, with an oval, concave shape, with expanded sides $[9,22]$. After hatching, the larvae leave the underside of the eggs, which are in contact with the upper leaf epidermis, and gets into the leaves [24] (Figure 3).

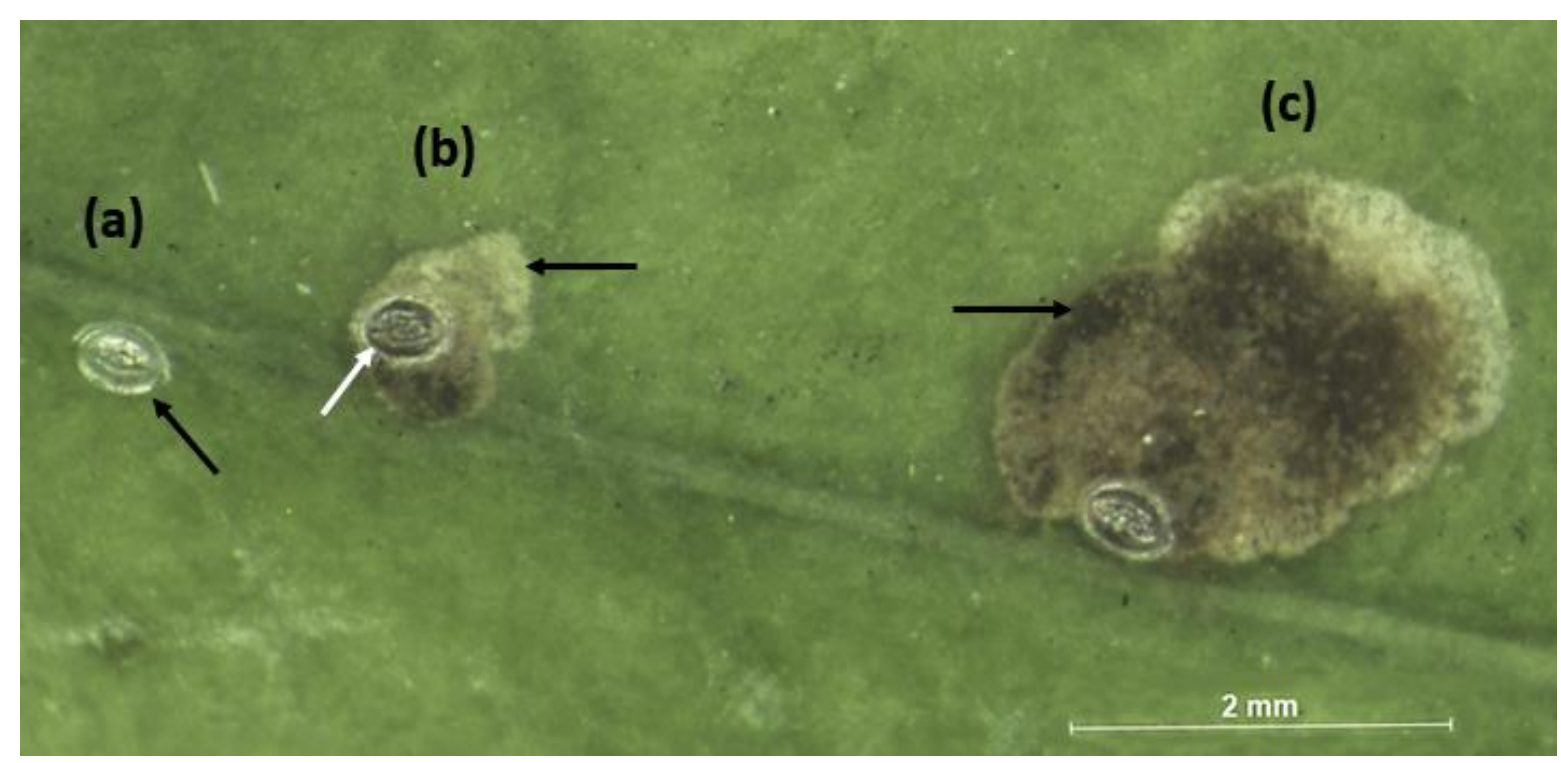

Figure 3. L. coffeella egg hatching and mine progression: (a) Unhatched eggs have a translucent structure, the arrow indicates a freshly oviposited egg; (b) After hatching, the eggshell becomes darker (white arrow) and the larva penetrates the leaf under the egg and starts feeding, forming a light green mine (black arrow); (c) Enlargement of the mine. The black arrow indicates the dark color of the mine due to residues left behind by the larva.

The L. coffeella larval phase has four instars [25]. Newly hatched larvae have a translucent whitish color, but throughout their development they take on a greenish yellow tone. The last larval instar is 
about 4-5 mm, flattened, segmented with 11 segments and yellowish in color [9,11] (Figure 4a). Fourth instar larvae have a flat head and mouthpiece of the chewing type (Figure $4 \mathrm{~b}, \mathrm{c}$ ), prolegs and brackets $[9,26]$ (Figure 4d).
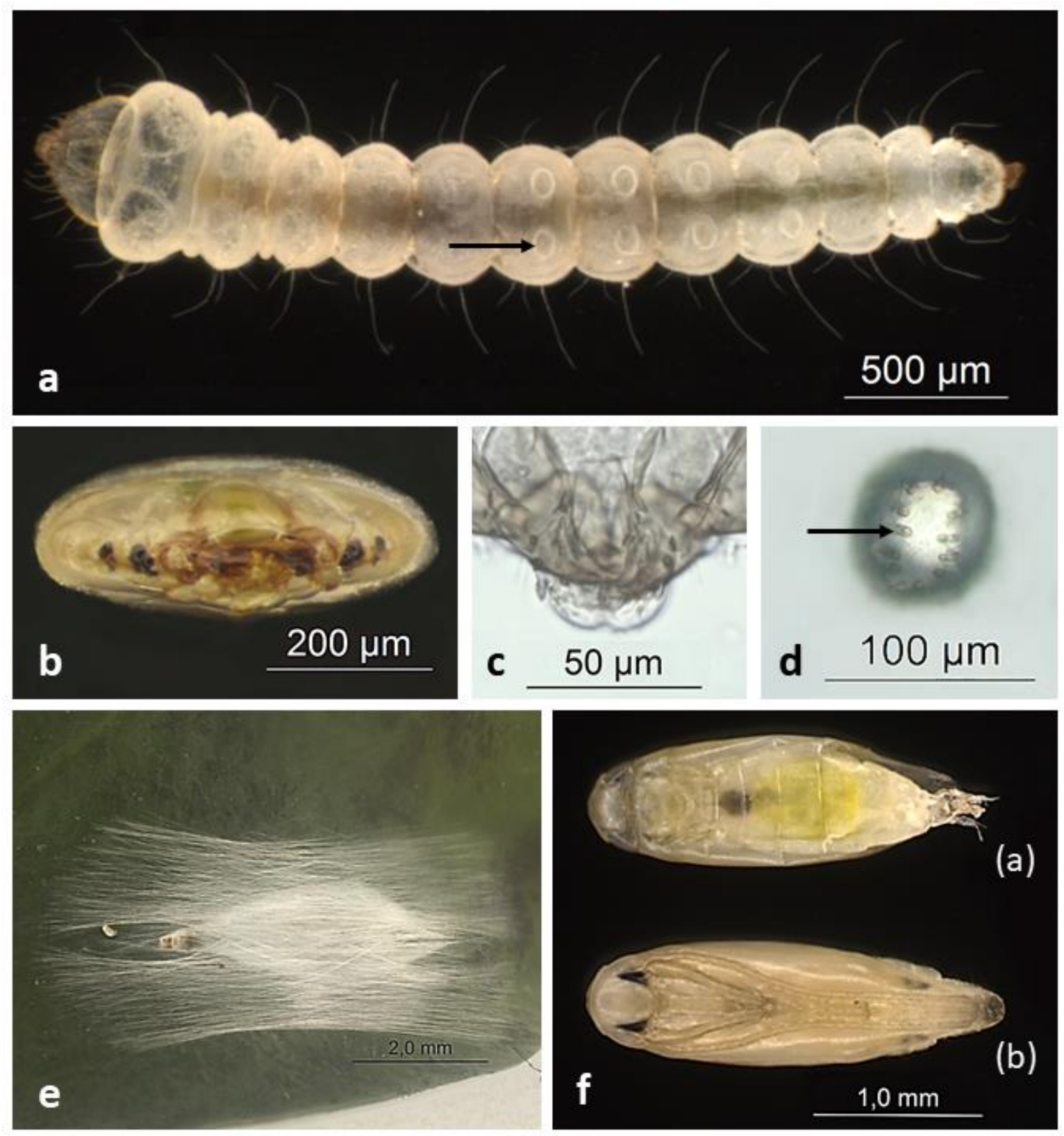

Figure 4. Immature stages of L. coffeella. (a) Ventral view of a fourth instar larva. Arrow indicates proleg; (b) Flat head in front view; (c) Chewing mouthpiece; (d) Brackets located in proleg. Arrow indicates bracket; (e) Pupa's sea cocoon, (f) Pupae's dorsal a, and ventral b shapes.

After accomplishing the larval stages, the larvae leave the mines and weave a silk X-shaped cocoon, usually in the axial region of the leaf, forming the pupae [9,22] (Figure 4e). Pupae have an approximate length of $2 \mathrm{~mm}$, milky color, small black eyes, antennas, and legs ventrally fused, and wrinkled wings [9] (Figure 4f). Usually, more pupae are found in the 'skirt' region of coffee plants, which is the underside of the plant where dead leaves accumulate. [24].

From pupae, adults emerge with an average body length of $2 \mathrm{~mm}$ and a wingspan of $6.5 \mathrm{~mm}$ (Figure 5a). They have a head with 'white hair scales', long antennae that reach the end of the 
abdomen, silver white chest, legs covered with white bristles, wing with three rows of yellow bristles at the apex with a black circle, yellowish abdomen and covered with white scales and genital organs covered by a tuft of white scales $[9,11]$ (Figure $5 \mathrm{~b}, \mathrm{c}$ ).
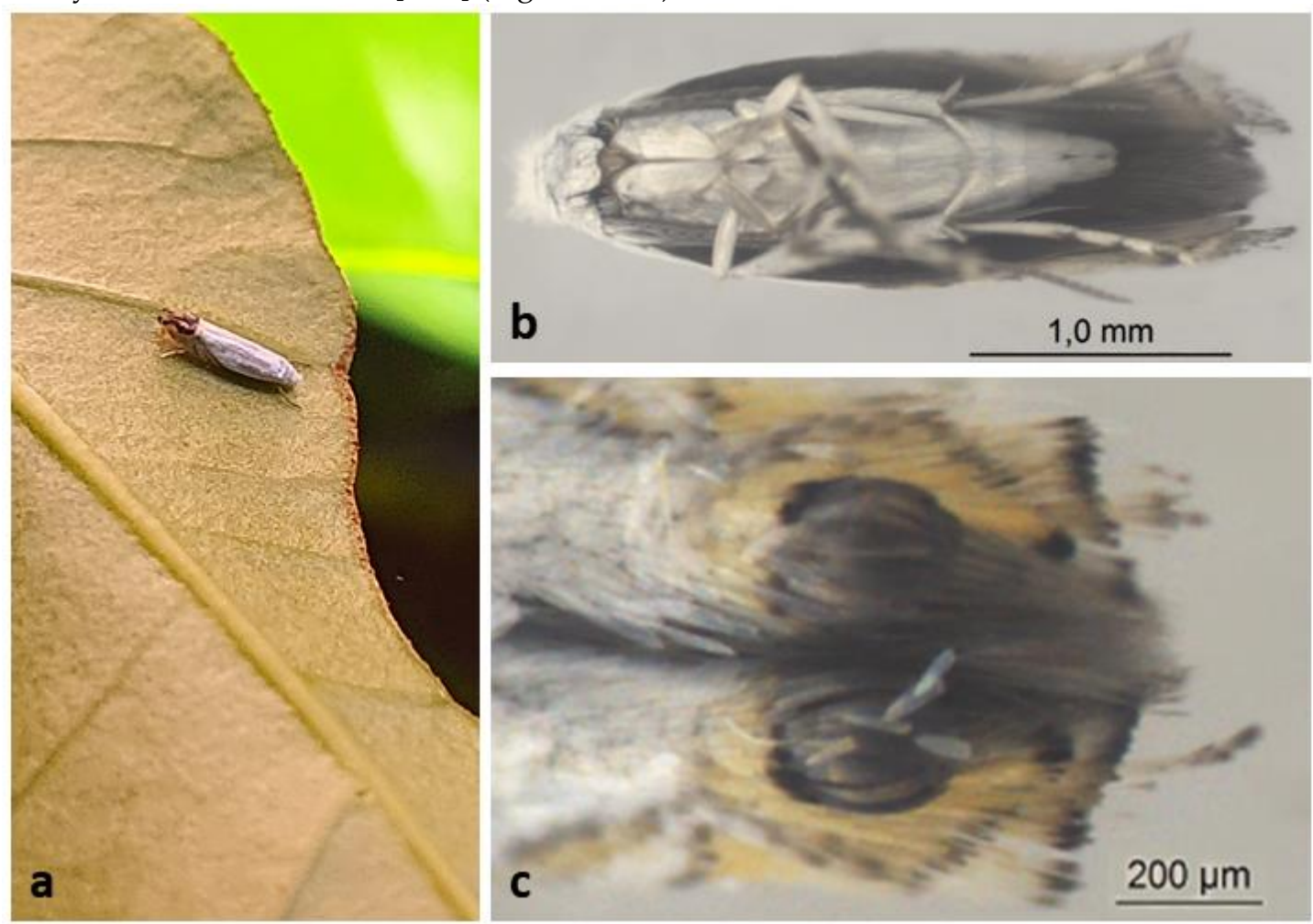

Figure 5. L. coffeella adults (a) perched on coffee leaf.; (b) seen by ventral view, with white scales all over the body; (c) closed caption of the wings apex from dorsal view to show details: black circle surrounded by yellow bristles.

\subsection{Larval feeding behavior}

CLM feeds only in coffee leaves [27] and the larvae are the causal agent of the crop damage. When feeding on the mesophyll of the coffee tree leaves, the insect creates mines that justify the common name of the pest - coffee leaf miner (Figure 6a). The mines cause necrosis (Figure 6b), decreasing the photosynthetic leaf surface (Figure $6 c$, d), leading to a lower photosynthetic rate of the plants and consequent depletion of the plant and productivity diminish [20]. The damage caused by this insect includes defoliation [22] (Figure 6e). Eventually, without adequate cultural treatments, the infestation can lead to the death of the plant.

A relationship between the feeding damage of CLM and the application of synthetic fertilizers has been described in the literature [28,29]. The amount of free amino acids and reducing sugars in the metabolic system of coffee plants is related to nutritional imbalance and susceptibility to pests. Plants fertilized with organic material showed a decrease of up to $50 \%$ of leaf mines [28]. 

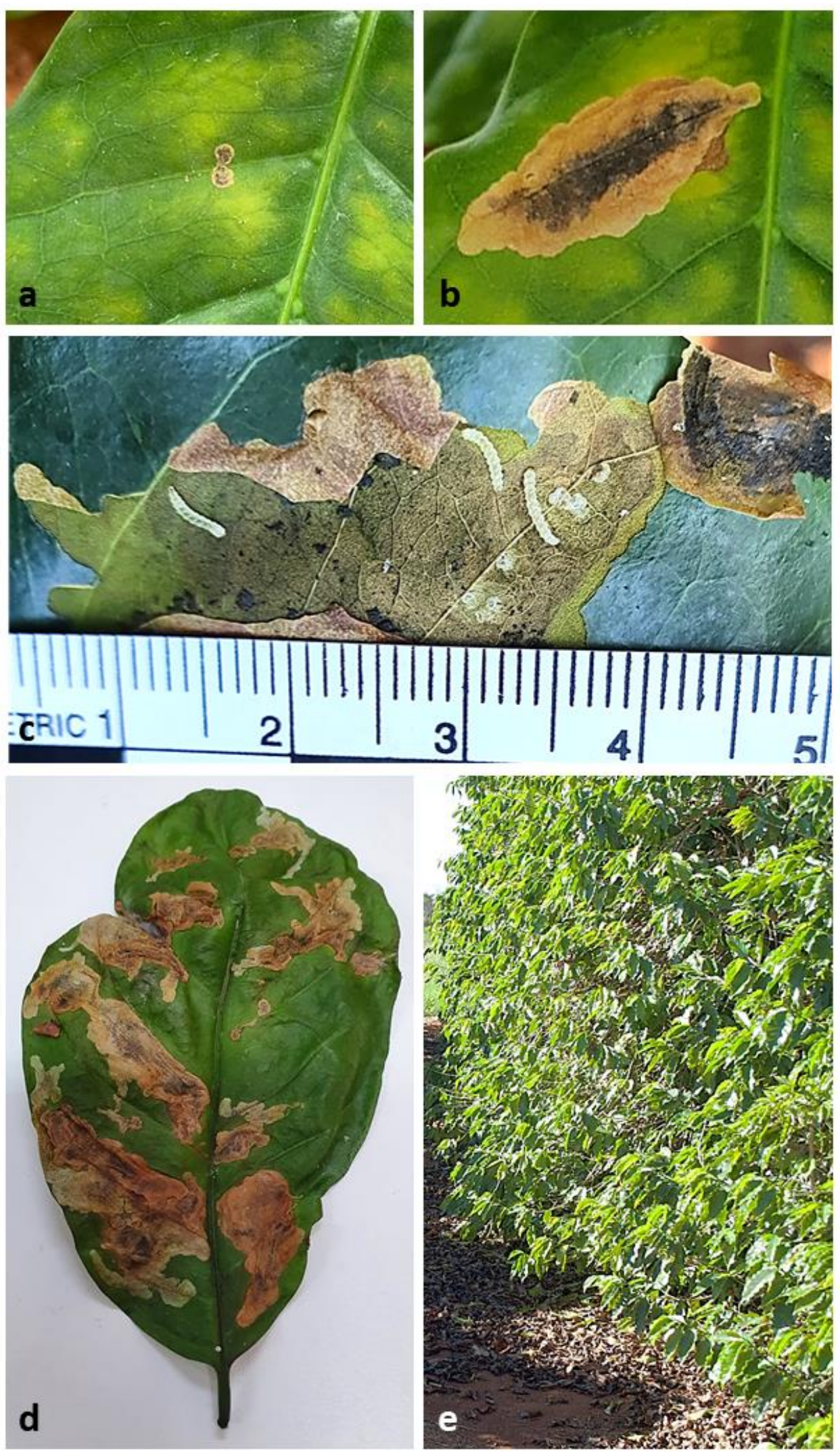

Figure 6. Damage to coffee leaf caused by the CLM larvae. (a) Initial mine formation; (b) Mine developed, with large necrotic area; (c) Larvae inside the mine; (d) Leaf with impaired photosynthetic surface; (e) Coffee defoliation. 


\subsection{Adult behavior}

L. coffeella is depicted as the quintessence of sensitivity level [23]. In adulthood, the insect has a nocturnal habit and during the day, it shelters beneath the coffee leaves [22]. Mating and laying occur preferably at night [25]; [24,30]. The sexual behavior of adults is very peculiar and can present the following stages, (1) females in a resting position with the abdomen curved downwards, exposing the pheromone gland in continuous movements from the inside out, to attract males; (2) when perceiving the pheromone, males remain in the same place, moving their antennae and flapping their wings, and then walk towards the female; (3) male touches the female with his antennae, female retracts the pheromone gland and places his abdomen towards the male; (4) the male places his abdomen towards the female abdomen, releases the edeago and fits the female, initiating copulation [31]. Females usually oviposit in the upper epidermis of the leaves at nightfall [22,24].

\section{Damage and Losses Caused by the CLM}

Brazil, Vietnam and Colombia are responsible for about $50 \%$ of the global production of coffee. The Brazilian coffee commodity comply more than one third of world coffee production and exports, figuring in the 5th place in Brazilian exportation agricultural trades [32,33] performing US\$ 1,3 billion in 2020 [34].

Until 1970 CLM outbreaks in coffee plantations in Brazil were sporadic because of the effective action of natural enemies on CLM population. Moreover, coffee crops used to be organized with narrow spacing, which is an adverse condition for this pest. In the 1970s, the mechanized model replaced the former one, requiring large areas of extensive agriculture with greater spacing between trees. The new plantation areas expanded onto drier and warmer regions, such as Brazilian Cerrado biome [20]

During their lifecycle CLM females are able to oviposit around seven eggs per night and more than 50 eggs during their lifetime [22]. Increased temperature in coffee fields often allows two CLM rounds in producer regions [21]. In a few days, the injuries area evolves from some millimeters to several centimeters (Figure 5) ending up to the falling of the leaves and lowering the productivity. The damage caused by the insect is not restricted to coffee, since current CLM control practices require pesticides that contaminate workers, consumers, and the environment.

\section{Control and Management of the CLM}

The hot climate shortens the plague cycle, resulting in remarkably high populations of adults, caterpillars and chrysalis, in addition to a large number of eggs in leaves [35]. On average, 8 generations can occur per year in Brazil, even reaching 12 during the crop year [36]. Climate change scenarios predict an increased infestation of CLM due to a greater number of generations per month $[17,37]$. The impact of climate change on C. arabica production was recently revised [38] Accurate models to estimate CLM levels of infestation are proposed [39].

Ideally, the first generation of the CLM must be controlled efficiently to prevent a growing population throughout the year. Chemical control is needed because the CLM reduces drastically the productivity of the C. arabica and C. canephora cultivars, otherwise the farmers would have to abandon their coffee growing activity. However, the chemical control used alone presents disadvantages for the environment, especially in relation to the survival of natural enemies, which are mostly affected by the products used for pest management. In addition, chemical control does not have complete efficiency, and several sprays are required, increasing the production costs. Finally, chemicals lose their effectiveness because they allow the selection of naturally resistant individuals, and consequent increase of resistant populations in field.

\subsection{Chemical control}


Nowadays the chemical control of CLM is mandatory for the maintenance of coffee crops. There are some active ingredients available and the most efficient are thiamethoxan [2], chlorantraniliprole [40], cartap hydrochloride [41]. Studies on the stability of those products detected their presence in plants up to eight and six months after application, respectively. The best performance in CLM control was observed with soil application for both systemic action and selectivity results $[2,42]$ verified thiamethoxam protection above 180 days whereas control plants without insecticide showed a drastic decrease of more than $50 \%$ in production.

Nowadays the chemical control of CLM is mandatory for the maintenance of coffee crops. There are some active ingredients available and the most efficient are thiamethoxan [2], chlorantraniliprole [40] cartap hydrochloride [41], lufenorum, and flupiradifurone. Studies on the stability of thiametoxan detected it presence in plants up to eight months after application in soil conferring protection against CLM and low effect in non-target insects (DIEZ-RODRÍGUEZ et al., 2006). SOUZA et al., 2006 verified thiamethoxam protection above 180 days whereas control plants without insecticide showed a drastic decrease of more than $50 \%$ in production.

Thus, chemical control has been required, especially in areas with high CLM incidence, such as the Brazilian Cerrado biome, which is characterized by high temperatures and long drought periods. The intensive use of chemical insecticides, however, can lead to pest resistance, especially when the same active ingredient is continuously used. In addition, chemical pesticides pose risks to workers and the environment. [43] recently reported that $94 \%$ of the populations were resistant to the active ingredient chlorantraniliprole in some producing areas of the Bahia state.

\subsection{Genetic resistance to CLM}

Coffee farming began in Brazil in 1727, with the Típica cultivar introduction. This genetic material was nearly the only one exploited in a commercial basis until the middle of the 19th century [44] Since then, several traits of interest, such as high yield and improved tolerance to diseases/pests and abiotic factors, have been introgressed using genetic breeding and generating several new cultivars. Those genetic breeding programs allowed the expansion of coffee growing in several biomes in the country. However, traditional cultivars such as Catuaí and Mundo Novo, and even other cultivars with higher levels of tolerance to other pests, suffer heavy CLM infestation.

\subsubsection{Breeding}

With regard to susceptibility to BMC, [45] classified the species of Coffea as: highly resistant - C. stenophyila, C. brevipes, C. liberica and C. salvatrix;moderately resistant - C. racemosa, C. kapakata, C. dewevrei and C. eugenioides, susceptible- C. congenesis, C. canephora and C. arabica. However, coffee breeding programs deal with serious limitations to perform interspecific hybridization of $C$. Arabica associated with the low genetic variability and the allotetraploid features of this commercial species [44].

The main source of resistance to BMC are plants derived from a natural cross between $C$. arabica and C. racemosa carried out in the 1950s (Medina, 1963). Subsequently, individuals belonging to the second generation of natural backcrosses (RC2) with C. arabica (Medina-Filho et al., 1977) were hybridized with commercial cultivars aiming at the development of cultivars resistant to the CLM (Carvalho, 2008). However, the inheritance of this traits remains unclear, which hinders its fixation in plants with high productivity and good quality grains. Currently, there are only two cultivars with resistance to the CLM in Brazil, Siriema AS1 [46], propagated by seeds, and Siriema VC4 [47], a clonal cultivar formed by the grouping of four clones. Clonal cultivars have the advantages of allowing the use of F1 hybrids and plants in segregation.

BMC tolerance has been observed in cultivars derived from the Sarchimor group, such as Obatã IAC 1669-20 and Tupi IAC 1669-33. In a comparative study [30], it was found that despite the higher 
percentage of leaves injured by the CLM, these cultivars were able to keep the leaves longer than Ouro Verde Amarelo IAC 4397, which can mitigate the pest damage. In addition, it was noticed that the destruction of the leaves is milder in C. canephora than in C. arabica.

Resistance to BMC may be of a biochemical nature [16] and larvae probably have a protective mechanism against a possible toxic effect of caffeine [48]. Data on the influence of chemical composition and leaf age (Guerreiro Filho, 2006) suggest that new leaves are more tolerant, with significant reduction in egg laying and increased larvae mortality, probably due to the higher concentration of secondary metabolites, such as phenols.

\subsubsection{Genetic modification}

The biotechnology achievements on genetic improvement of coffee plants were revised by [49], and more recently by [50]. Genetic engineering techniques were developed to $C$. arabica [51] and $C$. canephora [52] to express genes aiming to control coffee insect-pests.

Transgenic plants carrying the cry $1 A c$ gene from Bacillus thuringiensis showed good resistance to L. coffeella in greenhouse conditions and initial field experiments [53]. Nonetheless, the constitutive promoter $E F 1 \alpha-A 1$ provided too low Cry1Ac protein levels in the transgenic leaves to confer efficient and sustainable protection against $L$. coffeella in the field [54].

\subsection{Biological control of CLM}

Population dynamics of CLM can be strongly affected by host-plant attributes and environmental conditions, but also by the abundance of natural enemies [15], [55,56]. Parasitoids and predators (wasps and ants) have been extensively reported in coffee plantations in several Latin American and African countries since 1970s as natural mortality factors [4,57-62]. Despite the great number of hymenopteran species parasitizing Leucoptera sp. larvae in coffee growing areas worldwide (Supplementary Table 1) and their contribution on population dynamics of the pest, no significant attempt was made to use these natural enemies as biological control. As reviewed by [63], few cases of introduction of new parasitoids species or augmentation of indigenous species have been made for the suppression of CLM populations. Although unsuccessful in most of the cases, the author stressed the great potential of periodic releases of natural enemies of $L$. coffeella under certain conditions. Moreover, some invertebrate-pathogenic fungi were already tested against different developmental stages of species in Leucoptera genus. Eggs and larvae of L. coffeella were susceptible to infection by the fungus Metarhizium anisopliae [64]. Also, the species Beauveria bassiana was described as pathogenic to L. malifoliella, infecting last instar larvae when leaving the leaf mines for pupation after exposure to this pathogen [65].

Crop management practices and landscape structure can affect insect communities and the ecosystem services provided by natural enemies, enhancing their diversity and abundance. Ecologically complex coffee systems are associated with higher biodiversity of parasitoid wasps, ants, and other predators [66]. For instance, richness and abundance of social wasps is positively correlated with forest cover in coffee-producing regions, increasing L. coffeella predation [67].

\subsection{Semiochemicals}

Pheromones may be used to manipulate or disrupt the natural behaviors of insects to reduce population levels to diminish crop damage. Mass trapping offers a good alternative over huge plantations, disruption of mating processes to regional application, and "attract and kill" to smaller fields. 
5,9-dimethylpentadecan and 5,9-dimethylhexadecane are the main and secondary components of L. coffeella sexual pheromones[68,69]. [70] synthesized the four possible stereoisomers of 5,9dimethylpentadecane. Subsequently, [71]demonstrated the synthesis in 3 stages of a mixture of 5,9dimethylpentadecane stereoisomers that showed high biological activity in the field. The racemic mixture of pheromone components was synthesized from citronellol [72].

The female production pattern of 5,9-dimethylpentadecane is related to the period of the day and the time after adult emerging from pupa [73]. The results in virgin females showed that the higher amounts of pheromone were produced in the period comprised between $4 \mathrm{~h}$ before and $2 \mathrm{~h}$ after dawn and in 1day-aged females.

Host plants release volatiles which influence the mating and oviposition of lepidopterans and may increase biosynthesis of sexual pheromone. In the case of L. coffeella, the volatiles compounds liberated by the C. arabica plant increase the mating ratio by about $90 \%$. Moreover, they accelerate the onset of copulation and soar mating duration. The CLM oviposition observed in C. arabica was higher than in non-host plants [74].

\subsubsection{Monitoring}

The 5,9-dimethylpentadecane is indicated for the integrated management of the CLM. Delta trap monitoring [75] can be done by installing one trap for every 4ha. [31] used the traps $0.5 \mathrm{~m}$ above the ground containing synthetic sex hormone and observed that the peak of male capture occurs around noon, coinciding with the mating peak time.

\subsubsection{Mating disruption and mass trapping}

Mating disruption (MD) techniques provide prevention of mate location and mating, and factors that interfere with or delay the normal insect mating processes [77]. Successful cases have long been reported to codling moth in pome fruit, oriental fruit moth in peaches and nectarines, tomato pinworm in vegetables, pink bollworm in cotton and omnivorous leafroller in vineyards [77]. The management of caterpillars of the pine processionary moths Thaumetopoea was achieved in restricted areas using pheromones as a practical alternative to insecticide sprays[78]. Some mating disruption treatments are still to be improved [79-83], being CLM one of them.

The viability of MD to reduce coffee leaf miner populations by application of synthetic 5,9dimethylpentadecane was evaluated by synthetic-baited pheromone traps or the level of damage that the insect caused to the leaves. The results showed failure of the MD that may be attributed to a combination of several technical factors [84]. Dispenser types, like aerosol [85] or aerial applications [86], release points in the field and treatment period as yet to be tested to CLM control by confusion.

Recent advances are reported for lepidopteran pests in agriculture using "attract and kill" approaches [87]. Effectiveness of mass trapping (MT) by sticky traps was observed to the leopard moth in the olive orchards [88], the tea geometrid [89], chickpea pod borer [90].

\subsection{Bioproducts}

\subsubsection{Botanical pesticides}

Biopesticides based on plant sources present remarkable advantages over conventional synthetic chemical pesticides, including: lower persistence in the environment, lesser phytotoxicity, more effectiveness, higher specificity towards target organisms, reduced pest management costs, and a low toxicological and ecotoxicological risk for field workers, consumers and the environment [91]. 
Studies on the efficacy and the use of botanical pesticides has been largely reported in the literature, and even more, recommended by international organizations as a more sustainable manner to control pests [92-96]. Raw vegetal materials for biopesticide development are obtained from barks, leaves, roots, flowers, fruits, seeds, cloves, rhizomes, and stems of plants belonging to several botanical families. The derived substances from the materials processing are generally plant extracts, essential oils or both [97]_. Commercialized pesticides from plants, such as pyrethrum, neem and sabadilla, are some examples of biopesticides of the least toxicity to non-targets organisms, such as pollinators and fish [98].

Botanical aqueous extracts of (Toona ciliata, Trichilia casaretti, Trichilia pallida, Trichilia catigua, Chenopodium ambrosioides and Azadiracta indica) have been evaluated against CLM eggs, larvae and pupae under laboratory conditions. According to the results, the aqueous extract of $C$. ambrosioides and T. casaretti killed $50 \%$ of eggs against $45 \%$ for T. ciliata. Moreover, pupae treated with A. indica extract showed the highest level of mortality (100\%) followed by T. pallida $75 \%$ and C. Ambrosioides $62 \%$. In relation to larvae mortality, A. indica and T. pallida extracts were the most effective killing $70 \%$ against $50 \%$ observed for $C$. ambrosioides [99]. These results might be useful in integrated management programs for coffee leaf miner insect (L. coffeella). Activity against CLM larvae was reported by soaking treatment with extracts from Achillea millefolium, Citrus limon, Glechoma hederacea, Malva sylvestris, Mangifera indica, Mentha spicata, Mirabilis jalapa, Musa sapientum, Ocimum basiculum, Petiveria alliaceae, Porophyllum ruderale, Psidium guajava, Rosmarinus officinalis, Roupala montana, Sambucus nigra and Tropaeolum majus [100]. The extracts of Plantago lanceolata and Momordica charantiaplants reduced oviposition and egg hatching, and fecundity for females obtained from eggs treated with the M. charantia [101].

Combining biopesticides and nano-based delivery methods at the nanoscale is now being explored to increase efficacy while limiting the negative impacts traditionally seen through the use of pest control means [102]. Nanotechnology offers the advantages of using nanomaterials presenting novel and enhanced features compared to bulk materials. The remarkable physicochemical properties of these materials generate applications in agriculture as pesticides and platforms for gene delivery $[103,104]$.

\subsubsection{Nanobiopesticides}

Nanopesticides constitute nanoencapsulated (or nanoentrapped) pesticides, which can be bioactive compounds (biopesticides) and/or agrochemicals (e.g. insecticides), capable of controlling and inhibiting the growth of plant insect pests. Thus, nanobiopesticides comprise the encapsulation and/or entrapment of biopesticides, which are obtained from bacteria, fungi, plants, and animals (e.g. plant extracts and essential oils, fungal and bacterial biomolecules) [105]. The encapsulation not only optimizes stability, solubility, permeability, and specificity of pesticides, but also promotes a sustained release of them [106].

The agricultural nanoformulations are commonly based on metallic nanoparticles, polymeric nanoparticles, nanoemulsions, lipid nanoparticles, or carbon-based nanostructures. Silver nanoparticles (AgNPs) synthesized using the leaf extract of Annona reticulata, and the AgNPs showed insecticidal activity against Sitophilus oryzae, an insect that damages rice grains [107]. Nanemulsions produced with Pimpinella anisum essential oil presented activity against the red flour beetle (Tribolium castaneum), a stored grain pest [108]. Likewise, solid lipid nanoparticles produced with geranium essential oil (Pelargonium graveolens) were reported as a control agent of black cutworm Agrotis ipsilo [109]. Similarly, graphene oxide nanocomposites loaded with pesticides (pyridaben, chlorpyrifos, and beta-cyfluthrin) enhanced acaricidal activity against spider mite [110].

\section{Conclusions}


There is great demand for control products of this pest that are less toxic, highly specific, with less impact on the population of natural enemies, and that result in lower production costs (GABRIEL CASTILLO, 2016). Some biotechnological alternatives can generate products to meet the demand for sustainable, durable, and safe solutions for the specific control of this pest.

Development of coffee leaf miner resistant/tolerant cultivars remains a strong tendency. The current breeding programs began with $C$. arabica and C. racemosa crossings. Individuals belonging to the offspring of the second round of natural backcrosses (RC2) were hybridized with $C$. arabica commercial cultivars and generated new registered cultivars [111], [112] However, further investigation concerning the molecular basis of the resistance introgressed in C. arabica cultivars is required to keep the high-performance traits of grain yield and quality of the new genotypes.

CRISPR/Cas9 technology could circumvent some traditional breeding limitations to develop cultivars resistant to the CLM. Gene editing could provide both precise genome modifications and attenuation of regulatory restrictions on genetically engineered crops [113]. Despite the controversy surrounding GMOs in the agricultural sector, coffee is one of the very few woody species that has a validated protocol to mutate C. canephora with CRISPR/Cas9 A [114].

Biorational pesticides strategies to control L. coffeella must consider the important role of parasitoids, predators, and insect pathogens on enhancing the natural mortality of the CLM in field. Albeit biological control alone presents limitations in the efficiency and durability of treatments, it is positive in integrated control systems, in special to organic farming.

Promising results using plant extracts against CLM encourage the research of improved biopesticides to be integrated in more robust and sustainable pest management systems. Despite the lack of scientific papers describing the use of agricultural nanoformulations to control major coffee pests like the CLM, these recent advances to control pathogens and pests in other crops strongly suggest this possibility in the forthcoming years.

Author Contributions: Conceptualization, E.V.S.A.; writing-original draft preparation, J.D., I.M., L.V., J.B., J.M.P., A.D.V., C.H.S.C., R.B.L., N.B., T.LR.., L.P.S., J.R.P-L. and E.V.S.A.; writing-review and editing, J.D., I.M., A.D.V., C.H.S.C., R.B.L., T.LR.., L.P.S., J.R.P-L. and E.V.S.A; supervision, J.D., and E.V.S.A.; project administration, E.V.S.A.; funding acquisition, E.V.S.A.. All authors have read and agreed to the published version of the manuscript.

Funding: This research was funded by Consórcio Brasileiro de Pesquisa e Desenvolvimento do Café CBP\&D/Café and Embrapa, grant number 10.18.20.004.00.00. The fellowships of IM, LV, JB were funded by Fundação de Apoio à Pesquisa - FUNAPE.

Conflicts of Interest: The authors declare no conflict of interest. The funders had no role in the design of the study; in the collection, analyses, or interpretation of data; in the writing of the manuscript, or in the decision to publish the results. 


\section{Appendix A}

Table 1. Main hymenopteran species found in coffee growing areas parasitizing Leucoptera sp.

\begin{tabular}{|c|c|c|c|}
\hline Family & Species & $\begin{array}{c}\text { Country (a) } \\
\% \text { Parasitism (b) }\end{array}$ & Reference \\
\hline $\begin{array}{l}\text { Braconidae } \\
\text { Encyrtidae } \\
\text { Eulophidae }\end{array}$ & $\begin{array}{c}\text { Apanteles bordagei } \\
\text { Ageniaspis spp. } \\
\text { Cirrospilus variegatus } \\
\text { Closterocerus ritchiei (sin. } \\
\text { Achrysocharis ritchiei) } \\
\text { Elasmus leucopterae } \\
\text { Pediobius coffeicola }\end{array}$ & $\begin{array}{l}\text { (a) Tanzania } \\
\text { (b) } 20-75 \%\end{array}$ & [115] \\
\hline $\begin{array}{l}\text { Braconidae } \\
\text { Encyrtidae } \\
\text { Eulophidae }\end{array}$ & $\begin{array}{c}\text { Apanteles bordagei } \\
\text { Parahormius spp. } \\
\text { Ageniaspis spp. } \\
\text { Closterocerus ritchiei (sin. } \\
\text { Achrysocharis ritchiei) } \\
\text { Zagrammosoma variegatum } \\
\text { Pediobius coffeicola } \\
\text { Elasmus spp. } \\
\text { Chrysonotomyia spp. }\end{array}$ & $\begin{array}{l}\text { (a) Kenia } \\
\text { (b) } 17-32 \%\end{array}$ & [62] \\
\hline $\begin{array}{l}\text { Braconidae } \\
\text { Eulophidae }\end{array}$ & $\begin{array}{l}\text { Mirax insulatris } \\
\text { Achrysocharoides spp. } \\
\text { Zagrammosoma spp. } \\
\text { Cirrospiloideus spp. } \\
\text { Horismenus spp. } \\
\text { Chrysonotomyia spp. }\end{array}$ & $\begin{array}{l}\text { (a) Puerto Rico } \\
\text { (b) } 19.5-23.5 \%\end{array}$ & [116] \\
\hline $\begin{array}{l}\text { Braconidae } \\
\text { Eulophidae }\end{array}$ & $\begin{array}{c}\text { Centistidea striata } \\
\text { Orgilus niger } \\
\text { Stiropius reticulatus } \\
\text { Mirax spp. } \\
\text { Closterocerus coffeellae } \\
\text { Cirrospilus spp. } \\
\text { Horismenus spp. } \\
\text { Neochrysocharis coffeae } \\
\text { Proacrias coffeae } \\
\text { Tetrastichus spp. }\end{array}$ & $\begin{array}{l}\text { (a) Brazil } \\
\text { (b) } 8-44 \%\end{array}$ & $\begin{array}{l}{[60]} \\
{[15]} \\
{[55]}\end{array}$ \\
\hline $\begin{array}{l}\text { Braconidae } \\
\text { Eulophidae }\end{array}$ & $\begin{array}{c}\text { Allobracon spp. } \\
\text { Stiropius letifer } \\
\text { Cirrospilus spp. } \\
\text { Closterocerus spp. } \\
\text { Elachertus spp. } \\
\text { Horismenus spp. } \\
\text { Miotropis spp. } \\
\text { Neochrysocharis spp. } \\
\text { Pnigalio spp. } \\
\text { Zagrammosoma spp. }\end{array}$ & $\begin{array}{l}\text { (a) Mexico } \\
\text { (b) } \leq 10 \%\end{array}$ & [117] \\
\hline Eulophidae & $\begin{array}{c}\text { Zagrammosoma } \\
\text { multilineatum } \\
\text { Pnigalio sarasolai }\end{array}$ & $\begin{array}{l}\text { (a) Colombia } \\
\text { (b) } 58-89 \%\end{array}$ & [118] \\
\hline
\end{tabular}


Closterocerus spp.

Horismenus spp.

Apleurotropis spp.

\section{References}

1. Neves M.F. Análise dos Benefícios Econômicos e Sociais da Utilização do Carbofurano no controle de Nematoides, Bicho Mineiro (Leucoptera coffeella) e Cigarra do Cafeeiro (Quesada gigas e Fidicina pronoe) na Cultura do Café. Univ. Sao Paulo 2006, 29.

2. Souza, J.C. de; Reis, P.R.; Rigitano, R.L. de O.; Ciociola Júnior, A.I. Eficiência de thiamethoxam no controle do bicho-mineiro do cafeeiro. II - Influência na época de aplicação via irrigação por gotejamento. 2006.

3. Constantino C., L.M.; Florez V., J.C.; Benavides M., P.; Bacca I., R.T. Minador de las hojas del cafeto : Una plaga potencial por efectos del cambio climático; Centro Nacional de Investigaciones de Café (Cenicafé), 2013;

4. David-Rueda, G.; Constantino, L.M; Montoya, E.C.; Ortega, M.O.E.; Gil, Z.N.; BenavidesMachado, P. Diagnóstico de Leucoptera coffeella (Lepidoptera: Lyonetiidae) y sus parasitoides en el departamento de Antioquia, Colombia. Rev. Colomb. Entomol. 2016, 42, 4-11.

5. Giraldo J., M.; Postali P., J.R. Aspectos biológicos de Leucoptera coffeella Guérin Mèneville 1842 Lepidoptera : Lyonetiidae en coffea arabica en condiciones de laboratorio. Biological aspects of Leucoptera coffeella Guerin Meneville 1842 Lepidoptera : Lyonetiidae in coffea arabica under laboratory conditions 2017.

6. Vega, F.; Posada-Florez, F.; Infante, F. Coffee Insects: Ecology and Control. In Encyclopedia of Pest Managment; 2006; pp. 1-4.

7. Souto, L. A. Ocorrência de Leucoptera coffeella e detecção da presença de minas comparando amostragem convencional e amostragem por fotogrametria terrestre. 2019.

8. Vasconcelos, G.C. IDENTIFICAÇÃO DA PRAGA BICHO-MINEIRO EM PLANTAÇÕES DE CAFÉ USANDO IMAGENS AÉREAS E DEEP LEARNING. Univ. Uberlandia 2019, 30.

9. Box, H.E. The Bionomics of the White Coffee-leaf Miner, Leucoptera coffeella, Guér., in Kenya Colony. (Lepidoptera, Lyonetidae.). Bull. Entomol. Res. 1923, 14, 133-145, doi:10.1017/S0007485300056248.

10. Gallo, D.; O. Nakano; S.S. Neto; R.P.L. Carvalho; G.C. Batista; E.B. Filho; J.R.P. Parra; R.A. Zucchi; S.B. Alves; J.D. Vendramim Manual de entomologia agrìcola.; 2nd ed.; CERES, 1988; 
11. Guérin-Méneville, F.-E. (Félix-E.; 1799-1874; Perrottet, G.S. (George S.; 1793-1870 Mémoire sur un insecte et un champignon qui ravagent les cafiers aux Antilles. 1842.

12. Silvestri, F. Compendio di entomologica applicata (agraria, forestale, medica, veterinaria); Stab. tip. Bellavista, 1943;

13. Green, G. A proposed origin of the coffee leaf-miner, Leucoptera coffeella (Guerin-Meneville) (Lepidoptera:Lyonetiidae). Bull. Entomol. Soc. Am. 1984.

14. Mey, W. Taxonomische Bearbeitung der westpaläarktischen Arten der Gattung Leucoptera Hübner, '1825', s. 1. (Lepidoptera, Lyonetiidae) 'Taxonomic revision of the westpalaearctic species of the genus Leucoptera Hübner, “1825”, s. I. (Lepidoptera, Lyonetiidae).' Dtsch. Entomol. Z. 1994, 41, 173-234, doi:10.1002/mmnd.19940410119.

15. Pereira, E.J.G.; Picanço, M.C.; Bacci, L.; Lucia, T.M.C.D.; Silva, É.M.; Fernandes, F.L. Natural mortality factors of Leucoptera coffeella (Lepidoptera: Lyonetiidae) on Coffea arabica. Biocontrol Sci. Technol. 2007, 17, 441-455, doi:10.1080/09583150701309337.

16. Medina Filho, H.P.; Carvalho, A.; Mônaco, L.C. Melhoramento do cafeeiro: XXXVII Observações sobre a resistência do cafeeiro ao bicho-mineiro. Bragantia 1977, 36, 131-137, doi:10.1590/S0006-87051977000100011.

17. Ghini, R.; Hamada, E.; Júnior, M.J.P.; Marengo, J.A.; Gonçalves, R.R.V. Risk analysis of climate change on coffee nematodes and leaf miner in Brazil. Pesqui. Agropecuária Bras. 2008, 43, 187-194.

18. Pantoja-Gomez, L.M.; Corrêa, A.S.; de Oliveira, L.O.; Guedes, R.N.C. Common Origin of Brazilian and Colombian Populations of the Neotropical Coffee Leaf Miner, Leucoptera coffeella (Lepidoptera: Lyonetiidae). J. Econ. Entomol. 2019, 112, 924-931, doi:10.1093/jee/toy416.

19. Parra, J.R.P.; Gonçalves, W.; Precetti, A.A.C.M. Flutuação populacional de parasitos e predadores de Perileucoptera coffeella (Guérin-Méneville, 1842) em três localidades do estado de São Paulo. Turrialba 1981, 31, 357-364.

20. SOUZA, J. C. de; REIS, P. R.; RIGITANO, R. L. de O. Bicho-mineiro do cafeeiro: biologia, danos e manejo integrado. Available online: https://www.bdpa.cnptia.embrapa.br/consulta/busca?b=ad\&id=207009\&biblioteca=vazio\&bu sca=autoria:\%22REIS,\%20P.\%22\&qFacets=autoria:\%22REIS,\%20P.\%22\&sort=\&paginacao=t\& paginaAtual $=6($ accessed on Oct 20,2020$)$.

21. Katiyar, K.P.; Ferrer, F. Rearing technique, biology and sterilization of the coffee leaf miner, Leucoptera coffeella Guer. (Lepidoptera: Lyonetiidae). 1968. 
22. Costa, J.N.M.; Teixeira, C.A.D.; Júnior, J.R.V.; Rocha, R.B.; Fernandes, C. de F. Informações para facilitar a identificação das diferentes fases do bicho-mineiro (Leucoptera coffeella) em campo. 2012, 4 .

23. Wolcott, G.N. A quintessence of sensitivity: the coffee leaf-miner. J. Agric. Univ. P. R. 1947, 31, 215-219, doi:10.46429/jaupr.v31i3.12848.

24. Guerreiro Filho, O. Coffee leaf miner resistance. Braz. J. Plant Physiol. 2006, 18, 109-117, doi:10.1590/S1677-04202006000100009.

25. Notley, F.B. The Leucoptera leaf miners of coffee on Kilimanjaro; Leucoptera coffeella, Guér. Bull. Entomol. Res. 1948, 39, 399-416, doi:10.1017/s0007485300022501.

26. Nielsen, C.D. of The insects of Australia: a textbook for students and research workers; Carlton, VIC, Melbourne Univ. Press, 1991; ISBN 978-0-522-84454-2.

27. RENA, A.B.; MALAVOLTA, E.; ROCHA, M.; YAMADA, T. Pragas do Cafeeiro. In Rena AB et al (eds) Cultura do Cafeeiro - Fatores que afetam a produtividade. 1986, 447.

28. Sabino, P.H. de S.; Junior, F.A.R.; Carvalho, G.A.; Mantovani, J.R. NITROGEN FERTILIZERS AND OCCURRENCE OF Leucoptera coffeella (Guérin-Mèneville \& Perrottet) IN TRANSPLANTED COFFEE SEEDLINGS. 2018, 13, 410-414, doi:10.25186/cs.v13i3.1458.

29. Theodoro, V.C. de A.; Guimarães, R.J.; Mendes, A.N.G. Infestação por bicho-mineiro e teores foliares de açúcares solúveis totais e proteína em cafeeiros orgânicos. Coffee Sci. 2014.

30. Conceição, C.H.C.; Guerreiro-Filho, O.; Gonçalves, W. Flutuação populacional do bichomineiro em cultivares de café arábica resistentes à ferrugem. Bragantia 2005, 64, 625-631, doi:10.1590/S0006-87052005000400012.

31. Michereff, M.F.F.; Michereff Filho, M.; Vilela, E.F. Comportamento de acasalamento do bicho-mineiro-do-cafeeiro, Leucoptera coffeella (Guérin-Mèneville) (Lepidoptera: Lyonetiidae). Neotrop. Entomol. 2007, 36, 376-382, doi:10.1590/S1519-566X2007000300005.

32. Concafe Produção dos Cafés do Brasil atinge 61,62 milhões de sacas de 60kg em 2020, volume 25\% maior que 2019 Available online:

http://www.consorciopesquisacafe.com.br/index.php/imprensa/noticias/1023-2020-09-29-1522-05 (accessed on Oct 21, 2020).

33. Shahbandeh, M. Top coffee producing countries 2018 Available online: https://www.statista.com/statistics/277137/world-coffee-production-by-leading-countries/ (accessed on Oct 21, 2020).

34. Cecafé Relatório mensal setembro 2020 - Conselho dos Exportadores de Café do Brasil; 2020; 
35. P. R. Reis; JÚLIO CÉSAR DE SOUZA; Madelaine Venzon Manejo ecológico das principais pragas do cafeeiro. Inf. Agropecuário 2002, 23, 201-215.

36. JÚLIO CÉSAR DE SOUZA Café: Controle do bicho mineiro precisa ser feito a partir de agora para garantir grande safra em 20182017.

37. Jaramillo, J.; Muchugu, E.; Vega, F.E.; Davis, A.; Borgemeister, C.; Chabi-Olaye, A. Some Like It Hot: The Influence and Implications of Climate Change on Coffee Berry Borer (Hypothenemus hampei) and Coffee Production in East Africa. PLoS ONE 2011, 6, doi:10.1371/journal.pone.0024528.

38. Weldemichael, G.; Teferi, D. The Impact of Climate Change on Coffee (Coffea arabica L.) Production and Genetic Resources. Int. J. Res. Stud. Agric. Sci. 2019, 5, doi:10.20431/24546224.0511004.

39. de Oliveira Aparecido, L.E.; de Souza Rolim, G. Models for simulating the frequency of pests and diseases of Coffea arabica L. Int. J. Biometeorol. 2020, 64, 1063-1084, doi:10.1007/s00484020-01881-5.

40. Fragoso, D.B.; Guedes, R.N.C.; Guedes, R.N.C.; Picanço, M.C.; Zambolim, L. Insecticide use and organophosphate resistance in the coffee leaf miner Leucoptera coffeella (Lepidoptera: Lyonetiidae). Bull. Entomol. Res. 2002, 92, 203-212, doi:10.1079/BER2002156.

41. Melo, T.L.; Raetano, C.G.; Nery, M.S.; Cardoso, A.D.; Moreira, A.A.; Leite, S.A.; Jesus, T.F. de; Silva, W.G.O.; Castellani, M.A. Management of coffee leaf miner: spray volume, efficacy of cartap hydrochloride and impact on parasitism. 2019, doi:10.25186/cs.v14i2.

42. Diez-Rodríguez, G.I.; Baptista, G.C. de; Trevizan, L.R.P.; Haddad, M.L.; Nava, D.E. Resíduos de tiametoxam, aldicarbe e de seus metabólitos em folhas de cafeeiro e efeito no controle de Leucoptera coffeella (Guérin-Mèneville) (Lepidoptera: Lyonetiidae). Neotrop. Entomol. 2006, 35 , 257-263, doi:10.1590/S1519-566X2006000200016.

43. Leite, S.A.; Dos Santos, M.P.; Resende-Silva, G.A.; da Costa, D.R.; Moreira, A.A.; Lemos, O.L.; Guedes, R.N.C.; Castellani, M.A. Area-Wide Survey of Chlorantraniliprole Resistance and Control Failure Likelihood of the Neotropical Coffee Leaf Miner Leucoptera coffeella (Lepidoptera: Lyonetiidae). J. Econ. Entomol. 2020, 113, 1399-1410, doi:10.1093/jee/toaa017.

44. CARVALHO, C. H. S. Cultivares de café. Embrapa 2007.

45. Guerreiro Filho, O.; Medina Filho, H.P.; Carvalho, A. Fontes de resistência ao bicho-mineiro, Perileucoptera coffeella, em Coffea spp. Bragantia 1991, 50, 45-55, doi:10.1590/S000687051991000100006. 
46. Matiello, J.B.; Almeida, S.R. de; Silva, M.B. da; Ferreira, I.B.; Carvalho, C.H.S. de Siriema AS1, cultivar de cafeeiro com resistência à ferrugem e ao bicho mineiro. Siriema AS1, coffee cultivar with resistance to leaf rust and leaf miner 2015.

47. Matiello, J.B.; Almeida, S.R.; Silva, M.B. da; Ferreira, I.B.; Carvalho, C.H.S. Siriema VC4, cultivar clonal de cafeeiros com resistência múltipla, à ferrugem e ao bicho mineiro. 2015.

48. Guerreiro Filho, O.; Mazzafera, P. Caffeine Does Not Protect Coffee Against the Leaf Miner Perileucoptera coffeella. J. Chem. Ecol. 2000, 26, 1447-1464, doi:10.1023/A:1005587725704.

49. Mishra, M.K.; Slater, A. Recent Advances in the Genetic Transformation of Coffee. Biotechnol. Res. Int. 2012, 2012, 580857, doi:10.1155/2012/580857.

50. Villalta-Villalobos, J.; Gatica-Arias, A. A look back in time: genetic improvement of coffee through the application of biotechnology. Agron. Mesoam. 2019, 30, 577-599, doi:10.15517/am.v30i2.34173.

51. Barbosa, C.; Rezende, J.C. de; Carvalho, G.R.; Carvalho, A.M. de; Andrade, V.T.; Botelho, C.R. Adaptabilidade e estabilidade fenotípica de cultivares de café arábica em Minas Gerais. Pesqui. Agropecuária Bras. 2010, 45, 1404-1411, doi:10.1590/S0100-204X2010001200010.

52. Leroy, T.; Henry, A.-M.; Royer, M.; Altosaar, I.; Frutos, R.; Duris, D.; Philippe, R. Genetically modified coffee plants expressing the Bacillus thuringiensis cry1Ac gene for resistance to leaf miner. Plant Cell Rep. 2000, 19, 382-389.

53. Perthuis, B.; Pradon, J.; Montagnon, C.; Dufour, M.; Leroy, T. Stable resistance against the leaf miner Leucoptera coffeella expressed by genetically transformed Coffea canephora in a pluriannual field experiment in French Guiana. Euphytica 2005, 144, 321-329, doi:10.1007/s10681-005-8003-9.

54. Perthuis, B.; Vassal, J.-M.; Fenouillet, C.; Leroy, T. Cry1Ac insecticidal protein levels in genetically modified Coffea canephora Pierre coffee plants were negatively correlated with the growth speed in a field experiment. Euphytica 2015, 202, 373.

55. Amaral, D.S.; Venzon, M.; Pallini, A.; Lima, P.C.; DeSouza, O. Does vegetational diversification reduce coffee leaf miner Leucoptera coffeella (Guérin-Mèneville) (Lepidoptera: Lyonetiidae) attack? Neotrop. Entomol. 2010, 39, 543-548, doi:10.1590/S1519566X2010000400012.

56. Fernandes, F.L.; Mantovani, E.C.; Bonfim Neto, H.; Nunes, V.D.V. Efeitos de variáveis ambientais, irrigação e vespas predadoras sobre Leucoptera coffeella (Guérin-Méneville) (Lepidoptera: Lyonetiidae) no cafeeiro. Neotrop. Entomol. 2009, 38, 410-417, doi:10.1590/S1519-566X2009000300018. 
57. Bigger M. An investigation by Fourier analysis into the interaction between coffee leafminers and their larval parasites. J. Anim. Ecol. 1973.

58. Gallardo-Covas, F. Faunal survey of the coffee leaf miner, Leucoptera coffeella, parasitoids in Puerto Rico. J. Agric. Univ. P. R. 1988, 72, 255-263, doi:10.46429/jaupr.v72i2.7844.

59. Lomeli-Flores, J.R.; Barrera, J.F.; Bernal, J.S. Impact of natural enemies on coffee leafminer Leucoptera coffeella (Lepidoptera: Lyonetiidae) population dynamics in Chiapas, Mexico. Biol. Control 2009, 51, 51-60, doi:10.1016/j.biocontrol.2009.03.021.

60. Parra; Gonçalves, W; Gravena, S.;; Marconato, A.R. Parasitos e predadores do bicho-mineiro do cafeeiro Perileucoptera coffeella (Guérin-Méneville, 1842) em São Paulo. An. Soc. Entomológica Bras. 1977, 6, 138-143.

61. Picanço, M.; Oliveira, I.; Fernandes, F.; Prieto, M.; Bacci, L.; Silva, É. Ecology of Vespidae (Hymenoptera)Predators in Coffea arabica Plantations. Sociobiology 2012, 59, 1269-1280.

62. Wanjala, F.M.E. Relative abundance and within canopy distribution of the parasites of the coffee leafminer,Leucoptera meyricki [Lep.: Lyonetiidae] in Kenya. Entomophaga 1978, 23, 57-62, doi:10.1007/BF02371992.

63. Gallardo-Covas, F. Augmentation of Mirax insularism Muesebeck: Alternative for population control of the coffee leaf miner, Leucoptera coffeella Guérin-Ménéville, in Puerto Rico. J. Agric. Univ. P. R. 1992, 76, 43-54, doi:10.46429/jaupr.v76i2.4132.

64. Villacorta, A. (Instituto A. do P. Ovicidal activity of Metarhizium anisopliae isolate, CM-14 on the coffee leaf miner. Perileucoptera coffeella (Lep. : Lyonetiidae). Entomophaga Fr. 1983.

65. Draganova, S.A.; Tomov Virulence of a strain Beauveria bassiana (Bals.) Vuill. (Hyphomycetes, Deuteromycotina) against larvae of Leucoptera malifoliella Costa (Lepidoptera, Lyonetiidae). Bulg. J. Agric. Sci. 1998, 4, 435-439.

66. Iverson, A.; Gonthier, D.; Pak, D.; Ennis, K.; Burnham, R.; Perfecto, I.; Rodriguez, M.; Vandermeer, J. A multifunctional approach for achieving simultaneous biodiversity conservation and farmer livelihood in coffee agroecosystems. Biol. Conserv. 2019, 238, 108179, doi:10.1016/j.biocon.2019.07.024.

67. Medeiros, H.R.; Grandinete, Y.C.; Manning, P; Harper, K.A; Cutler, G.C; Tyedmers, P; Righi, C.A; Ribeiro, M.C. Forest cover enhances natural enemy diversity and biological control services in Brazilian sun coffee plantations. Agron. Sustain. Dev. 2019, 39.

68. Francke, W.; Toth, M.; Szöcs, G.; Krieg, W.; Ernst, H. Identification and synthesis of dimethylalkanes as sex attractants of female leaf minor moths.. Z Naturforsch 1988, 43C, 787789. 
69. Malo, E.A.; Rojas, J.C.; Lopez-Guillen, G.; Barrera, J.F. Chemical Analysis of Female Volatiles and Field Response of the Coffee Leafminer Moth (Lepidoptera: Lyonetiidae) to Stereoisomers of Its Major Sex Pheromone Component. Fla. Entomol. 2009, 92, 548-553.

70. Kuwahara, S.; Liang, T.; Leal, W.S.; Ishikawa, J.; Kodama, O. Synthesis of all four possible stereoisomers of 5,9-dimethylpentadecane, the major sex pheromone component of the coffee leaf miner moth, Perileucoptera coffeella. Biosci. Biotechnol. Biochem. 2000, 64, 2723-2726, doi:10.1271/bbb.64.2723.

71. Zarbin, P.H.G.; Princival, J.L.; de Lima, E.R.; dos Santos, A.A.; Ambrogio, B.G.; de Oliveira, A.R.M. Unsymmetrical double Wittig olefination on the syntheses of insect pheromones. Part 1: Synthesis of 5,9-dimethylpentadecane, the sexual pheromone of Leucoptera coffeella. Tetrahedron Lett. 2004, 45, 239-241, doi:10.1016/j.tetlet.2003.10.183.

72. Doan, N.N.; Le, T.N.; Nguyen, H.C.; Hansen, P.E.; Duus, F. Ultrasound Assisted Synthesis of 5,9-Dimethylpentadecane and 5,9-Dimethylhexadecane - the Sex Pheromones of Leucoptera coffeella. Mol. J. Synth. Chem. Nat. Prod. Chem. 2007, 12, 2080-2088, doi:10.3390/12082080.

73. Lima, E.R.; Vilela, E.F.; Della Lucia, T.M.C.; Ataíde, L.M.S. Age and time related pheromone production in coffee leafminer Leucoptera coffeella Guérin-Méneville (Lepidoptera: Lyonetiidae). J. Braz. Chem. Soc. 2008, 19, 1659-1662, doi:10.1590/S0103-50532008000800030.

74. Fonseca, M. das G.; Araújo, A.P.A.; Resende, T.T. de; Lima, E. Influence of host plant on reproductive behavior of Leucaoptera coffeella (Guerin-Meneville) (Lepidoptera: Lyonetiidae). Coffee Sci. Braz. 2013.

75. Lima, E.R. de Feromônio sexual do bicho-mineiro do café, Leucoptera coffeella: Avaliação para uso em programas de Manejo Integrado.

76. Ibarra, B.; Libio, R.T. Monitoramento de Leucoptera coffeella com armadilha de feromônio sexual. Monitoring of Leucoptera coffeella with sexual pheromone traps 2006.

77. Cardé, R.T.; Minks, A.K. Control of Moth Pests by Mating Disruption: Successes and Constraints. Annu. Rev. Entomol. 1995, 40, 559-585, doi:10.1146/annurev.en.40.010195.003015.

78. Trematerra, P.; Colacci, M. Recent Advances in Management by Pheromones of Thaumetopoea Moths in Urban Parks and Woodland Recreational Areas. Insects 2019, 10, doi:10.3390/insects10110395.

79. Lo Verde, G.; Guarino, S.; Barone, S.; Rizzo, R. Can Mating Disruption Be a Possible Route to Control Plum Fruit Moth in Mediterranean Environments? Insects 2020, 11, 589, doi:10.3390/insects11090589. 
80. Lance, D.R.; Leonard, D.S.; Mastro, V.C.; Walters, M.L. Mating Disruption as a Suppression Tactic in Programs Targeting Regulated Lepidopteran Pests in US. J. Chem. Ecol. 2016, 42, 590-605, doi:10.1007/s10886-016-0732-9.

81. Thiéry, D.; Louâpre, P.; Muneret, L.; Rusch, A.; Sentenac, G.; Vogelweith, F.; Iltis, C.; Moreau, J. Biological protection against grape berry moths. A review. Agron. Sustain. Dev. 2018, 38, 15, doi:10.1007/s13593-018-0493-7.

82. Michaelakis, A.; Anastasaki, E.; Milonas, P.G.; Papachristos, D.P.; Kontodimas, D.; Pontikakos, C.M.; Raptopoulos, D.G.; Babilis, N.A.; Konstantopoulou, M.A. Efficacy of communication disruption of Thaumetopoea pityocampa (Lepidoptera: Thaumetopoeidae) with low pheromone formulation. Hell. Plant Prot. J. 2020, 13, 42-53, doi:10.2478/hppj-20200005.

83. Frank, D.L.; Starcher, S.; Chandran, R.S. Comparison of Mating Disruption and Insecticide Application for Control of Peachtree Borer and Lesser Peachtree Borer (Lepidoptera: Sesiidae) in Peach. Insects 2020, 11, 658, doi:10.3390/insects11100658.

84. Ambrogi, B.G. Viabilidade da técnica de confusão sexual de machos para o controle do bicho-mineiro do café Leucoptera coffeella (Guérin-Méneville) (Lepidoptera: Lyonetiidae). 2004.

85. Benelli, G.; Lucchi, A.; Thomson, D.; Ioriatti, C. Sex Pheromone Aerosol Devices for Mating Disruption: Challenges for a Brighter Future. Insects 2019, 10, 308, doi:10.3390/insects10100308.

86. Régnière, J.; Delisle, J.; Dupont, A.; Trudel, R. The Impact of Moth Migration on Apparent Fecundity Overwhelms Mating Disruption as a Method to Manage Spruce Budworm Populations. Forests 2019, 10, 775, doi:10.3390/f10090775.

87. Welter, S.; Pickel, C.; Millar, J.; Cave, F.; Van Steenwyk, R.; Dunley, J. Pheromone mating disruption offers selective management options for key pests. Hilgardia 2005, 59, 16-22.

88. Hegazi, E.; Khafagi, W.E.; Konstantopoulou, M.; Raptopoulos, D.; Tawfik, H.; El-Aziz, G.M.A.; El-Rahman, S.M.A.; Atwa, A.; Aggamy, E.; Showeil, S. Efficient Mass-Trapping Method as an Alternative Tactic for Suppressing Populations of Leopard Moth (Lepidoptera: Cossidae). Ann. Entomol. Soc. Am. 2009, 102, 809-818, doi:10.1603/008.102.0507.

89. Wang, Z.; Ma, T.; Mao, T.; Guo, H.; Zhou, X.; Wen, X.; Xiao, Q. Application technology of the sex pheromone of the tea geometrid Ectropis grisescens (Lepidoptera: Geometridae). Int. J. Pest Manag. 2018, 64, 372-378, doi:10.1080/09670874.2018.1447170.

90. Madhu, T.; Shah, V.; Prabhulinga, T.; Chakravarthy, A.; Ashok Kumar, C. Optimization of pheromone trap densities and impact of insecticides on pheromone catches for mass 
trapping Helicoverpa armigera (Hubner) (Lepidoptera: Noctuidae) in chickpea. J. Entomol. Zool. Stud. 2019, 7, 78-84.

91. Isman, M.B. Botanical Insecticides in the Twenty-First Century - Fulfilling Their Promise? Annu. Rev. Entomol. 2020, 65, 233-249, doi:10.1146/annurev-ento-011019-025010.

92. Ahmad, K.W.; Freed, S.; Shoukat, R.F. Efficacy of entomopathogenic fungi and botanicals on development of Musca domestica. J. Entomol. Zool. Stud. 2017, 7.

93. FAO Biopesticides for locust control | FAO Stories | Food and Agriculture Organization of the United Nations Available online: http://www.fao.org/fao-stories/article/en/c/1267098/ (accessed on Oct 21, 2020).

94. Gakuubi, M.M.; Wagacha, J.M.; Dossaji, S.F.; Wanzala, W. Chemical Composition and Antibacterial Activity of Essential Oils of Tagetes minuta (Asteraceae) against Selected Plant Pathogenic Bacteria Available online: https://www.hindawi.com/journals/ijmicro/2016/7352509/ (accessed on Oct 21, 2020).

95. Isman, M. Commercial development of plant essential oils and their constituents as active ingredients in bioinsecticides. 2020, doi:10.1007/s11101-019-09653-9(.

96. Vidyasagar, G.M.; Tabassum, N. Antifungal investigations on plant essential oils. A review. Int. J. Pharm. Pharm. Sci. 2013, 5, 19-28.

97. Mizubuti, I.; Pereira Pinto, A.; Ribeiro, E.; Fey, R.; Palumbo, G.; Alves, T. Avaliação da silagem de bagaço de laranja e silagem de milho em diferentes períodos de armazenamento DOI: 10.4025/actascianimsci.v29i4.995. Acta Sci. Anim. Sci. 2007, 29, doi:10.4025/actascianimsci.v29i4.995.

98. Dubey, N.; Shukla, R.; Kumar, A.; Singh, P.; Prakash, B. Prospects of botanical pesticides in sustainable agriculture. Curr. Sci. 2010, 98.

99. Fanela, T.L.M.; Bentivenha, J.P.F.; Baldin, E.L.L.; Santana, A.S. Assessing potential plants extracts to reduce Leucoptera coffeella (lepidoptera: Lyonetiidae) attack in coffee. 2020, 15, e151653-e151653, doi:10.25186/.v15i.1653.

100. Alves, D.S.; Oliveira, D.F.; Carvalho, G.A.; Carvalho, D.A.; Souza, L.P.; Lasmar, O. Selection of active plant extracts against the coffee leaf miner Leucoptera coffeella (Lepidoptera: Lyonetiidae). Rev. Bras. Plantas Med. 2013, 15, 352-362, doi:10.1590/S1516-05722013000300007.

101. Alves, D.S.; Oliveira, D.F.; Carvalho, G.A.; Santos Jr, H. dos; Carvalho, D.A.; Santos, M. a. I.; Carvalho, H. de Plant Extracts as an Alternative to Control Leucoptera coffeella (GuérinMèneville) (Lepidoptera: Lyonetiidae). Neotrop. Entomol. 2011, 40, 123-128, doi:10.1590/S1519-566X2011000100019. 
102. Koul, O. Nano-Biopesticides Today and Future Perspectives; Academic Press, 2019; ISBN 978-012-815830-2.

103. Duhan, J.S.; Kumar, R.; Kumar, N.; Kaur, P.; Nehra, K.; Duhan, S. Nanotechnology: The new perspective in precision agriculture. Biotechnol. Rep. Amst. Neth. 2017, 15, 11-23, doi:10.1016/j.btre.2017.03.002.

104. Saranya, K.; Sundaramanickam, A.; Srinath, R.; Thangavelu, R.; Sathishkumar, R.S; Moorthy, M.; Parthasarathy, S. Green synthesis of silver nanoparticles by bloom forming marine microalgae Trichodesmium erythraeum and its applications in antioxidant, drug-resistant bacteria, and cytotoxicity activity. J. Saudi Chem. Soc. 2019, 23.

105. Krishnamurthy; Veerasamy; Karruppaya A Review on Plant Sources for Nano Biopesticide Production. Lett. Appl. NanoBioScience 2020, 9, 1348-1358, doi:10.33263/LIANBS93.13481358.

106. Prasad, R.; Bhattacharyya, A.; Nguyen, Q.D. Nanotechnology in Sustainable Agriculture: Recent Developments, Challenges, and Perspectives. Front. Microbiol. 2017, 8, doi:10.3389/fmicb.2017.01014.

107. Malathi; Nishanthi; P., P. Green synthesis and characterization of bioinspired silver, gold and platinum nanoparticles and evaluation of their synergistic antibacterial activity after combining with different classes of antibiotics. Mater. Sci. Eng. C 2019, 96, 693-707, doi:10.1016/j.msec.2018.11.050.

108. Hashem, A.S.; Awadalla, S.S.; Zayed, G.M.; Maggi, F.; Benelli, G. Pimpinella anisum essential oil nanoemulsions against Tribolium castaneum-insecticidal activity and mode of action. Environ. Sci. Pollut. Res. Int. 2018, 25, 18802-18812, doi:10.1007/s11356-018-2068-1.

109. Adel, M.M.; Salem, N.Y.; Abdel-Aziz, N.F.; Ibrahim, S.S. Application of new nano pesticide Geranium oil loaded-solid lipid nanoparticles for control the black cutworm Agrotis ipsilon (Hub.) (Lepi., Noctuidae). EurAsian J. Biosci. 2019, 9.

110. Wang, Y.; Liu, Y.; Gong, X.; Xie, Z.; Dong, Q.; Dong, M.; Liu, H.; Shao, Q.; Lu, N.; Murugadoss, V.; et al. Amino Graphene Oxide/Dopamine Modified Aramid Fibers: Preparation, Epoxy Nanocomposites and Property Analysis. Polymer 2019, 168, doi:10.1016/j.polymer.2019.02.021.

111. Andreazi, E.; Sera, G.H.; Faria, R.T. de; Sera, T.; Shigueoka, L.H.; Carvalho, F.G.; Carducci, F.C.; Chamlet, D. Desempenho de híbridos F1 de café arábica com resistência simultânea a ferrugem, mancha aureolada e bicho mineiro. 2015.

112. Carvalho Cultivares de café: origem, características e recomendações. Embrapa Café 2008.

113. Dort, E.N.; Tanguay, P.; Hamelin, R.C. CRISPR/Cas9 Gene Editing: An Unexplored Frontier for Forest Pathology. Front. Plant Sci. 2020, 11, doi:10.3389/fpls.2020.01126. 
114. Breitler, J.C.; Dechamp, E.; Campa, C.; Rodrigues, L.A.Z.; Guyot, R.; Marraccini, P.; Etienne, H. CRISPR/Cas9-mediated efficient targeted mutagenesis has the potential to accelerate the domestication of \#Coffea canephora\#. Plant Cell Tissue Organ Cult. 2018, 134, 383-394.

115. Bigger M. An investigation by Fourier analysis into the interaction between coffee leafminers and their larval parasites. J. Anim. Ecol. 1973.

116. Gallardo-Covas, F. Distribution of the coffee leaf miner, Leucoptera coffeella, and its parasitoids in the canopy of coffee, Coffea arabica in Puerto Rico. J. Agric. Univ. P. R. 1988, 72, 141-146, doi:10.46429/jaupr.v72i1.6843.

117. Lomeli-Flores, J.R.; Barrera, J.F.; Bernal, J.S. Impact of natural enemies on coffee leafminer Leucoptera coffeella (Lepidoptera: Lyonetiidae) population dynamics in Chiapas, Mexico. Biol. Control 2009, 51, 51-60, doi:10.1016/j.biocontrol.2009.03.021.

118. David-Rueda, G.; Constantino, L.M; Montoya, E.C.; Ortega, M.O.E.; Gil, Z.N.; BenavidesMachado, P. Benavides-Machado, P. Diagnóstico de Leucoptera coffeella (Lepidoptera: Lyonetiidae) y sus parasitoides en el departamento de Antioquia, Colombia. Rev. Colomb. Entomol. 2016, 42, 4-11. 